\title{
Do different industries report Corporate Social Responsibility differently? An investigation through the lens of stakeholder theory
}

\author{
Lorraine Sweeney* and Joseph Coughlan \\ Faculty of Business, Dublin Institute of Technology, Dublin, Ireland
}

\begin{abstract}
The social responsibility of business has become a major issue in recent years and the reporting of such activity is becoming more prevalent. Companies are attuning to the benefits of being seen as socially responsibly and many industries are jumping on the bandwagon of reporting CSR and using different media to communicate their activities in this arena to their stakeholders. This paper considers the content of one type of such communications, the annual report, and looks at how organisations are taking a focused stakeholder view of CSR rather than a wider view as would be expected from the ambiguity of definitions of the concept. Differences in reporting practices were found by an analysis of the annual and CSR reports of 28 FTSE4Good firms focusing on a variety of industries. Findings show that there is a significant difference between how organisations in different industries report on CSR consistent with a stakeholder view of CSR, and that this reporting follows for the most part the expectations of the CSR communications literature. It is suggested that firms report on CSR in line with what their key stakeholders expect, thus giving evidence for CSR reporting as another tool in the marketing communicators toolbox.
\end{abstract}

Keywords: Corporate Social Responsibility; stakeholder theory; annual reports

\section{Introduction}

Despite a wealth of literature on the subject, Corporate Social Responsibility (CSR) remains a broad, complex and continually evolving concept that encompasses a variety of ideas and practices (Hopkins 2003). It has been described as an ambiguous (Fisher 2004), subjective (Frederick 1986), unclear (McWilliams 2001), amorphous (Margolis and Walsh 2001) highly intangible (Cramer, Jonker, and Heijden 2004) fuzzy (McGuire 1963) concept with unclear boundaries and debatable legitimacy (Lantos 2001). Beliefs and attitudes regarding the nature of CSR have also varied over time (Hill, Stephens, and Smith 2003). A wide variety of definitions have been proposed, however more recent definitions of CSR tend to focus on a firm's responsibility toward its various stakeholders (Spence, Coles, and Harris 2001; Vos 2003; Jones 2005).

While much of the communication by larger public companies is voluntary, organisations are required to report to their owners at least once a year, and the mechanism to do this traditionally is the annual report. Organisations have added to the annual report over the years and it now contains more than is legally required: the presentation of the accounts of the organisation over the last financial period accompanied by a report from the directors and the auditors. In recent years, the annual report has started to contain information on how the organisation is

*Corresponding author. Email: lorraine.sweeney@dit.ie 
discharging its social responsibilities. Although the area of social accounting is undoubtedly growing (Rasche and Esser 2006), research in the area notes that the process is controlled by management and as such the legitimacy of the scope of the reporting may be questionable (Owen et al. 2000).

Extant research (Reynolds, Schultz, and Hekman 2006) shows that organisations orient themselves to different stakeholder groups. Stakeholder theory as popularised by Freeman (1984) discusses the constituent members of these groups as having a 'stake' in the organisation. Podnar and Jančič (2006, 299) note that given the competitive environment organisations find themselves in, organisations '.. . do not and cannot treat all stakeholders equally or communicate with them with the same intensity'. This research seeks to understand how, in the determination of the content of the annual report; communications specialists orient their organisations towards these different stakeholders. In order to achieve this aim a group of acknowledged CSR best practice organisations was chosen to explore, not only the range of stakeholders that the annual reports addressed, but primarily to assess if the industry the organisation operated within specified which stakeholders the organisations focused on in these reports as the literature in the communication of CSR suggests.

The paper unfolds as follows. The first section of the literature review discusses stakeholder theory. The second section explores the premise that there is an industry effect to the practice and indeed the reporting of CSR. Following the literature review the methodology used in this paper, content analysis will be outlined and the rationale for the choice of organisation in the study elaborated on. The findings will be presented and conclusions and recommendations for research and marketing communications practice will be drawn.

\section{Literature review}

\section{Stakeholder theory}

Freeman's (1984) now classic definition of stakeholders, arguably the most popular definition cited in the literature (Kolk and Pinske 2006, 60), proposed that stakeholders are 'any group or individual who can affect or is affected by the achievement of a corporation's purpose'. This is clearly a very broad definition and leaves the notion of stake and the fields of possible stakeholders unambiguously open to include virtually everyone (Maio 2003). Providing more clarity, Clarkson (1995) distinguishes between 'primary' and 'secondary' stakeholders. A primary or participant stakeholder, (Metcalfe 1998), is one without whose continuing participation the corporation cannot survive as a going concern. Secondary or non-participant stakeholders, (Metcalfe 1998), are defined as those who influence or affect, or are influenced or affected by the corporation, but they are not engaged in transactions with the corporation and are not essential for its survival. Balancing these different types of stakeholders has been shown to have an effect on financial performance (Reynolds, Schultz, and Hekman 2006).

Stakeholder theory recognises the fact that most, if not all firms have a large and integrated set of stakeholders (Cochran 1994) to which they have an obligation and responsibility (Spence, Coles, and Harris 2001). The theory challenges the view that shareholders have a privilege over other stakeholders (Orts and Strudler 2002). 
Shareholders, it is argued, are merely one of the several claimants on the firm (Heath and Norman 2004). This theory embodies the need to balance the claims of shareholders with these of other stakeholders (Ruf et al. 2001) and through this balancing act, the organisation can attract and maintain the support of their stakeholders (Reynolds, Schultz, and Hekman 2006). The idea that organisations face a non-homogenous set of stakeholder views has recently been conceptualised by Rasche and Esser (2006) using Habermasian discourse ethics. These multiple views may be integrated and Neville and Menguc (2006) discuss how different stakeholders may even work together to achieve a common goal, or indeed may be diametrically opposed to each other on an issue effecting the organisation.

In recent years, stakeholder attributes have received increasing attention (Frooman 1999) to aid managers in deciding how to allocate their limited time, energy and other scarce resources to different stakeholder groups (Vos 2003; Philips 2004). According to Cooper et al. (2001), when stakeholder theory is used as a managerial tool it is specifically concerned with identifying which stakeholders are more important, and as a result should receive a greater proportion of management attention. It is clear that different stakeholder groups can present quite different, and often conflicting, needs and interests (Neville and Menguc 2006; Sen, Bhattacharya, and Korschun 2006).

Mitchell, Agle, and Wood (1997) identify urgency, legitimacy and power as important stakeholder attributes, arguing that in their various combinations these attributes are indicators of the amount of management attention awarded to a given stakeholder. Power relates to the ability to bring about outcomes of desire or the ability of one actor within a social relationship to have another actor do something that they would not otherwise have done (Mitchell, Agle, and Wood 1997). Legitimacy is the perception or belief that stakeholders' claims are proper, desirable or appropriate (Thorne, Ferrell, and Ferrell 2003). Urgency is based on two characteristics; time sensitivity and importance of the claim to the stakeholder (Thorne, Ferrell, and Ferrell 2003). In addition, Sachs et al. (2006) distinguish four categories of stakeholders as benefit providers/receivers and/or risk providers/ bearers. Stakeholders may be granted different levels of salience depending on the number of categories into which they fall. The main stakeholder groups include shareholders, employees, customers, the local community and the environment (Cooper et al. 2001; Wulfson 2001; Lepoutre and Heene 2006). It also important to note that a single person may have different stakes in the organisation, for example they may be a customer, a prospective employee or an investor (Neville and Menguc 2006).

\section{Industry effect}

Thirty years ago, Sturdivant and Ginter (1977) highlighted the need to take a firms industry into account when studying CSR, a theme reinforced by Boutin-Dufresne and Sacaris (2004) who argue that firms in a particular industry may be more socially responsible simply by the nature of their activities. Cottrill (1990) argues that any investigation of CSR that fails to incorporate industry level realities will be fatally deficient. While Cowen, Ferreri, and Parket (1987) and Balabanis, Philips, and Lyall (1998) report that disclosure does not differ by industry type; Waddock and Graves (1997) found great difference in CSR disclosure across industries. Simpson and 
Kohers (2002) concentrated on the banking industry and argue that differences between industries with regard to CSR is so great that research needs to stick to just one industry.

There has been some 'single industry' research in the CSR area. Sachs et al. (2006) focused their analysis on Orange Communications in Switzerland and found that the firm devoted much attention to employees. They believe this to be the case because employees are both benefit providers/receivers and risk providers/receivers. 'Comparing the social performance of an oil company, where environmental and employee safety issues are likely to be paramount, with a high street retailer in effect makes no sense' (Moore 2001, 304). Moore (2001) focused on the supermarket industry and looked at CSR through the stakeholders: employees, customers, shareholders, suppliers, community and environment but did not analyse which stakeholder groups were granted more attention, etc. by firms. Hamid (2004) conducted a content analysis of the Annual Reports of 48 firms in the financial services industry and reported that firms in this industry focus on customers and employees as primary stakeholders. Mitnick (2000) observes that firms that have a negative impact on one area of CSR (for example, the environment) will not report this to a great extent, but instead will report other areas where they have a positive impact (such as charitable donations). Cooper et al. (2001) suggests that companies dealing directly with individual consumers are motivated to focus attention on this particular stakeholder.

\section{Methodology}

\section{Content analysis}

Content analysis has been widely employed in CSR research (Gray, Kouchy, and Lavers 1995b) and is the most common method of analysing social and environmental disclosure in firms (Milne and Adler 1999). Content analysis is, at its simplest, a research technique used to determine the presence of certain words or concepts within text. Stempel $(1981,119)$ suggested a broad view of content analysis, what he called 'a formal system for doing something that we do informally rather frequently, drawing conclusions from observations of content'. Krippendorff (1980, 21) was more informative, emphasising reliability and validity, he defined content analysis as 'a research technique for making replicable and valid inferences from data to their context'.

\section{Annual reports}

The annual report can be seen as a channel for the communication of messages within independent systems (Gray, Kouchy, and Lavers 1995a). Whilst companies are increasingly using a variety of alternative reporting media to report their CSR activities including interim reports, newspaper advertisements, press releases and company websites, in most cases, if not all, the annual report is the only document that is automatically sent to the shareholders by all companies (Adams, Hill, and Roberts 1998). It represents the main communication method used by firms to disclose CSR information (O'Dwyer 2003), though increasingly this report itself is also available online for other stakeholders to view (de Bussy, Ewing, and Pitt 2003). 
The annual report has some clear advantages over other forms of communication. Gray, Kouchy, and Lavers (1995a) argue that although corporate social reporting has been a subject of substantial academic accounting research for over two decades, the literature does not possess an overall coherence. However, this study found little differences in the format of annual and CSR reports across firms, thus they would seem to represent, as argued by Nafez and Kamal (2000), an ideal method for cross firm comparative purposes. The use of annual reports is also in line with previous research in the area (Gray, Kouchy, and Lavers 1995a, 1995b; Milne and Adler 1999; O'Dwyer 2003). Furthermore annual reports are required to be consistent with the financial statements presented therein and auditors must ensure that material in the annual report is not misleading and does not provide information that will damage the 'true and fair' view of the accounts.

Critics of annual reports as a CSR methodology tool point to the discrepancy between social disclosure and actual performance. According to McGuire, Sundgren, and Schneeweis (1988), to use annual reports as a measure of CSR is to confuse social orientation with corporate action. While annual reports have received much criticism as a measure of CSR, for the purpose of this study they are not being used as a measure of CSR but as an indicator of the type (as oppose to extent) of CSR conducted by firms, representing a response to Margolis and Walsh's (2001) call for research on how firms conduct CSR. This study followed the assumption highlighted by Krippendorff (1980) that the extent of disclosure can be taken as some indication of the importance of an issue to the reporting entity.

Employing a technique similar to Carroll (1994) it was decided to have two assessors analyse each annual and CSR report. According to Milne and Adler (1999), reliability can be increased by using a second assessor, an aspect of content analysis that is often neglected. From the literature surveyed, it became clear that the industry the firm operates within should have a significant effect on the stakeholders addressed in the firm's annual report.

The top ten firms on the FTSE4Good Global, UK, US and European Indices were taken as at December 2004. There was some overlap in the list but the final amount came to 30 firms that could be classified as being within six different industries. The FTSE4Good indices were taken as these companies are acknowledged as being leaders in CSR, and therefore would be an exemplar for other companies in their respective industries in this area. Furthermore Collinson et al. (2007) and Knox, Maklan, and French (2005) also used FTSE4Good listed firms and it has been described as one of the most important indices to consider (Marquez and Fombrun 2005).

Given the six different industries found, the literature suggested that the firms should focus on certain stakeholders more than they should focus on others. These were further classified into primary and secondary upon a further review of the extant literature, and it can be seen in Table 1. For those industries without significant literature (namely pharmaceutical), experts in the area were consulted and as a result pharmaceutical was split into two distinct groups due to the different groups each type is oriented towards.

The coding of the reports as oriented towards different stakeholder groups was agreed by both assessors and discrepancies were discussed. Primary stakeholder groups were agreed to be those groups to whom the reports were addressed and had the predominance of coverage in the report. Secondary stakeholders were those that 
Table 1. Stakeholder groups expected to be found.

\begin{tabular}{lll}
\hline Industry & \multicolumn{1}{c}{ Primary } & Secondary \\
\hline Financial Services & Customers, employees & Community \\
Pharmaceutical - Medical & Community & Employees \\
Pharmaceutical - Health \& Beauty & Customers & Environment \\
Telecommunications & Customers & Employees \\
Automobile & Environment & Customers \\
Oil \& Gas & Environment & Customers \\
Retail & Customers, employees & Community \\
\hline
\end{tabular}

had an important though less dominant role than the primary group or groups. In all the results were very similar between both assessors.

\section{Findings and discussion}

Table 2 shows the results of the analyses with expected results highlighted in bold. It is clear from a review compared to Table 1 that the expected results did not materialise in their entirety though the general thrust of the results show that firms in an industry do conform to the norms set by that industry. It is important to note that all of the reports mentioned all of the stakeholder groups in one form or another but the depth of focus on these groups differed significantly. Some organisations just identified primary stakeholders and a clear secondary stakeholder was not evident, hence the total number of stakeholders does not add to a multiple of the number of cases in each situation. Following previous work by Podnar and Jančič (2006), other stakeholders were also identified but the major focus of the reports did not point to any group other than those listed in the tables.

Many of the organisations studied had separate annual and CSR reports. The specific CSR reports, where they existed, were always summarised in the annual report. The majority of organisations also provided extra CSR information online

Table 2. Stakeholder groups found.

\begin{tabular}{|c|c|c|c|c|c|c|}
\hline \multirow[b]{2}{*}{ Industry } & \multicolumn{6}{|c|}{ Stakeholders } \\
\hline & Cases & Customer & Employees & Communities & Shareholders & Environment \\
\hline Financial Services & 8 & $4 \mathrm{P}^{\mathrm{a}}, 1 \mathrm{~S}$ & $6 \mathrm{P}^{\mathrm{a}}$ & $3 \mathrm{P}, 3 \mathrm{~S}$ & & \\
\hline $\begin{array}{l}\text { Pharmaceutical - } \\
\text { Medical }\end{array}$ & 3 & & $1 \mathrm{P}, 2 \mathrm{~S}$ & $2 \mathrm{P}^{\mathrm{a}}$ & & \\
\hline $\begin{array}{l}\text { Pharmaceutical - } \\
\text { Health \& Beauty }\end{array}$ & 2 & $2 \mathrm{P}^{\mathrm{a}}$ & $2 \mathrm{P}$ & $2 \mathrm{P}$ & $2 \mathrm{~S}$ & \\
\hline Telecommunications & 4 & $4 \mathrm{P}^{\mathrm{a}}$ & $2 \mathrm{~S}$ & & & \\
\hline Automobile & 4 & & & & & $4 \mathrm{P}$ \\
\hline Oil \& Gas & 4 & & $1 \mathrm{~S}$ & $1 \mathrm{~S}$ & & $4 \mathrm{P}$ \\
\hline Retail & 3 & $2 \mathrm{P}^{\mathrm{a}}$ & & & & $2 \mathrm{P}, 1 \mathrm{~S}$ \\
\hline
\end{tabular}

Note: P, primary stakeholder identified; S, secondary stakeholder identified.

${ }^{\mathrm{a}}$ Those expected as per Table 1 . 
and referred to it in their annual reports. The assessors noted that it was consistent with the material in the annual and CSR reports but this was not assessed in this piece of research. This is in keeping with the trend identified by de Bussy, Ewing, and Pitt (2003) to report CSR online.

The annual and CSR reports highlighted that CSR was defined and described by reference to their responsibility to a variety of stakeholders. This supports the literature arguing CSR can be most practically explained by reference to stakeholder theory (Spence, Jeurissen, and Rutherfoord 2000; Vos 2003; Jones 2005). One bank noted that 'Corporate Social Responsibility or CSR, means addressing the expectations of our customers, shareholders, employees and other stakeholders in managing our business responsibly and sensitively for long term success'.

More specifically, CSR activities were communicated as their responsibilities and policies with regard their main stakeholder groups; namely, customers, employees, suppliers, shareholders, the environment and the wider community. This is in line with the arguments of Clarkson (1995) and Metcalfe (1998) who discuss the formation of primary and secondary groups of stakeholders in organisations and also the groups identified in the literature review as those which were most frequently used (Cooper et al. 2001; Lepoutre and Heene 2006).

An interesting finding from this research, though not unexpected given the CSR literature, is the lack of a clear focus on the benefits for the shareholder as a specific stakeholder. Although it is common to assume that the shareholder may also be part of other stakeholder groups, for example customers or indeed employees (Sen, Bhattacharya, and Korschun 2006; Neville and Menguc 2006), it is unusual not to see them directly communicated with as a group within the annual and CSR reports of the firms studied (Orts and Schulder 2006). Only one of the industries placed any focus on them and this is surprising considering that annual and CSR reports are sent to shareholders, and therefore, from a communications perspective, this should be the prime audience of the reports. It is clear therefore that the idea of stakeholder multiplicity put forward by Sen, Bhattacharya, and Korschun (2006) and Neville and Menguc (2006) among others is being ascribed to by many organisations.

Primary stakeholders as customers and communities in the financial services industry was not unexpected, and was in line with previous research by Hamid (2004), though the lack of a clear focus on neither shareholders nor the environment was quite unusual given the prevalence of such information in the communications of many organisations (Dando and Swift 2003). The focus on employees was not in keeping with the results of Hamid (2004) though not totally unexpected given the pressures that organisations in that industry face with regard to recruitment and selection.

As can be seen from Table 2, the two sub-groups of the pharmaceutical industry exhibited different characteristics. The health and beauty part of the industry focused on a wider range of issues and stakeholders and were the only industry group to put a substantial emphasis on their shareholders in their report. Interestingly neither part of the industry focused on environmental issues to a great extent. The medical side of the industry concentrated on community as a group and to a lesser extent, employees as expected. This lack of focus on the customers may be due in part to the intermediated nature of their business as providers of products to health professionals rather than the public. 
The firms in the telecommunications industry met expectations. This industry is growing and as a result, the focus is on customer acquisition and retention. It is perhaps a little surprising given the nature of the product that there is not a larger emphasis on the environment though all reports did stress their responsibilities to the environment.

In the automobile industry, the focus of CSR rests on environmental performance. While one may expect such a finding owing to the impact on environmental performance caused by this industry, such findings are in contrast to the argument made by Mitnick (2000) that firms that have a negative impact on one area of CSR (here the environment) will not report this to a great extent but instead will report other areas where they have a positive impact (such as charitable donations). One automobile firm noted that it 'assumes its responsibility [for environmental impacts and demands on infrastructure] as an international automobile manufacturer by enhancing its products and carrying out research on a more effective design of the entire transport system'.

The oil and gas industry also placed emphasis on environmental performance. In line with extant research (Cooper et al. 2001; Carlisle and Faulkner 2004), one oil company argued that 'the nature of our business means that we must constantly consider the impacts that our operations and our products have upon the environment'.

Cooper et al. (2001) argued that companies dealing directly with individual consumers are motivated to focus attention on this particular stakeholder. This study found that companies operating in the retail industry concentrated on their customers and to a lesser extent, the environment. Interestingly those retailers that also operated forecourt petrol stations were seen to be more focused on environmental issues. The lack of a more distinct focus on employees was a little surprising given the nature of the industry.

This would seem to indicate that firms through the reporting of their CSR activities are conforming to expectations of the behaviour within their industry. It also highlights the importance of industry as a control variable for studies investigating the CSR activities of a group of firms.

\section{Conclusions, implications and further research}

This study set out to investigate the presence of a 'specialisation' of social interests in each industry, as argued by Griffin and Mahon (1977). This was found to be the case, which supports findings from Robertson and Nicholson (1996). Table 2 shows the key findings of the paper showing a clear industry effect in the reporting of CSR by the different organisations. The wider implications of this study of 30 large public firms operating in a global environment are that these are the organisations that smaller, more local, players will turn to in drafting their own communications policies and practices and they, as prize-winners for CSR, will be emulated by those companies. The lack of a clear emphasis on stakeholders shows that perhaps communications specialists are cognisant of the wider purview of shareholders as stakeholders (Sen, Bhattacharya, and Korschun 2006) and recognise that the shareholders of today may also have other stakes in the business (Neville and Menguc 2006).

This study has a number of implications for marketing communications specialists in organisations. The drafting of the annual report is not just directed at shareholders and it should try to appeal to as many stakeholders as possible given the industry 
within which the firm operates. Reporting of CSR practice towards your primary and secondary stakeholders is expected by the industry and it would be worthwhile, if not already available, to understand the needs and wants of those stakeholders in advance. It is also becoming commonplace for best practice organisations to draft a separate CSR report as well as the items on CSR in the annual report. Communications specialists in this area would do well to familiarise themselves with the literature on social reporting from an accounting perspective so that they can gain the benefit of the rules set down by the different international bodies in the area. It is also important to note that the annual report seems to have a multiplicity of audiences and communications specialists in the area need to be aware of this.

This study only considered one piece of evidence in the reporting of CSR, the annual report. Both assessors noted that extra online material was available in the majority of cases and that the annual report specifically directed the reader to such material. This material was not specifically studied for this paper; however, the assessors did read the information and found it to be consistent with the material in the annual report. The 28 companies chosen are not representative of the wide variety of firms that report on CSR but they were chosen because they are recognised for their CSR, and therefore, could be exemplars of best practice. A different sample of companies may have yielded different results than those found here.

Future research could extend and deepen the research by assessing CSR in different industries, researching more deeply in single industries and assessing the changes in CSR over time in a sample of organisations. The current sample, taken from the FTSE4Good indices, is not representative of the entire gamut of firms in the economy, nor indeed was it intended to be. Future research could look at a broader and more representative sample of firms to report on and assess. Communication of CSR is not solely through the mechanism of the annual report and it would be interesting to consider the differences, if any, between the different media used in its communication. Further research could also be carried out with the writers of the reports to understand their conceptualisation of the audience for whom they are writing the reports.

Focusing on a single industry to understand CSR is fraught with difficulties as this research found substantial differences between and within six different industries as to how they conceptualise CSR with regard to their stakeholders. It is clear from this research that a stakeholder approach is a useful one in conceptualising not only the practice of CSR but also its communication to various audiences. Communication of CSR is generally to an audience of stakeholders in line with expectations.

\section{Notes on contributors}

Lorraine Sweeney is a lecturer of strategic management at the Dublin Institute of Technology and is curently undertaking a PhD in the area of Corporate Social Responsibility.

Joseph Coughlan is acting Head of the School of Accounting and Finance at the Dublin Institute of Technology.

\section{References}

Adams, C., W. Hill, and C. Roberts. 1998. Corporate social reporting practices in Western Europe: Legitimising corporate behaviour? British Accounting Review 30: 1-12. 
Balabanis, G., H. Philips, and J. Lyall. 1998. Corporate Social Responsibility and economic performance in the top British companies: Are they linked? European Business Review 98, no. 1: 25-44.

Boutin-Dufresne, F., and P. Savaria. 2004. Corporate Social Responsibility and financial risk. The Journal of Investing 13: 57-66.

Carlisle, Y., and D. Faulkner. 2004. Corporate Social Responsibility: A stages framework. European Business Journal 16, no. 4: 143-52.

Carroll, A. 1994. Social issues in management research: Experts views, analysis and commentary. Business and Society 33, no. 1: 5-29.

Clarkson, M. 1995. A stakeholder framework for analysing and evaluating social performance. Academy of Management Review 20, no. 1: 92-118.

Cochran, P. 1994. The Toronto conference: Reflections on stakeholder theory. Business and Society 33, no. 1: 95-8.

Collinson, D., G. Cobb, D. Power, and L. Stevenson. 2007. The financial performance of the FTSE4Good indices. Corporate Social Responsibility and Environmental Management forthcoming 10.1002/csr.144.

Cooper, S., D. Crowther, M. Davies, and E. Davis. 2001. Shareholder or stakeholder value: The development of indicators for the control and measurement of performance. London: The Chartered Institute of Management Accountants.

Cottrill, H. 1990. Corporate Social Responsibility and the marketplace. Journal of Business Ethics 9: 723-29.

Cowen, S., L. Ferreri, and L. Parket. 1987. The impact of corporate characteristics on social responsibility disclosure: A typology and frequency based analysis. Accounting, organisation and Society 12, no. 2: 111-22.

Cramer, J., J. Jonker, and A. Heijden. 2004. Making sense of Corporate Social Responsibility. Journal of Business Ethics 55: 215-22.

Dando, N., and T. Swift. 2003. Transparency and assurance: Minding the credibility gap. Journal of Business Ethics 44: 195-200.

de Bussy, N., M. Ewing, and L. Pitt. 2003. Stakeholder theory and internal marketing communications: A framework for analysing the influence of new media. Journal of Marketing Communications 9: 147-161.

Frederick, W. 1986. Toward CSR3: Why ethical analysis is indispensable and unavoidable in corporate affairs. California Management Review XXVIII, no. 2: 126-41.

Freeman, E. 1984. Strategic management, A stakeholder approach. London: Pitman Publishers.

Frooman, J. 1994. Stakeholder Influence Strategies. Academy of Management Review 24, no. 2 : 191-206.

Gray, R., R. Kouchy, and S. Lavers. 1995a. Corporate social and environmental reporting: A review of the literature and longitudinal study of UK disclosures. Accounting, Auditing and Accountability Journal 8, no. 2: 47-77.

- 1995b. Methodological themes: Constructing a research database of social and environmental reporting by UK companies. Accounting, Auditing and Accountability Journal 8, no. 2: 78-101.

Griffin, J., and F. Mahon. 1997. The corporate social performance and corporate financial performance debate: Twenty-five years of incomparable research. Business and Society 36, no. 1: 5-32.

Hamid, F. 2004. Corporate social disclosure by banks and finance companies: Malaysian evidence. Corporate Ownership \& Control 1, no. 4: 118-30.

Heath, J., and W. Norman. 2004. Stakeholder theory, corporate governance and public management: What can the history of state-run enterprises teach us in the post-Enron era? Journal of Business Ethics 53: 247-65.

Hill, R., D. Stephens, and I. Smith. 2003. Corporate social responsibility: An examination of individual firm behaviour. Business and Society Review 108, no. 3: 339-64. 
Hopkins, M. 2003. The planetary bargain, Corporate Social Responsibility matters. London: Earthscan Publications Ltd.

Jones, M. 2005. The traditional corporation, Corporate Social Responsibility and the 'outsourcing' debate. The Journal of American Academy 2: 91-97.

Knox, S., S. Maklan, and P. French. 2005. Corporate Social Responsibility: Exploring stakeholder relationships and programme reporting across leading FTSE companies. Journal of Business Ethics 61, no. 1: 7-28.

Kolk, A., and J. Pinkse. 2006. Stakeholder mismanagement and Corporate Social Responsibility crises. European Management Journal 24, no. 1: 59-72.

Krippendorff, K. 1980. Content analysis: An introduction to its methodology. London: Sage Publications.

Lantos, G. 2001. The boundaries of strategic Corporate Social Responsibility. Journal of Consumer Marketing 18, no. 7: 595-632.

Lepoutre, J., and A. Heene. 2006. Investigating the impact of firm size on small business social responsibility: A critical review. Journal of Business Ethics 67, no. 3: 257-73.

Maio, E. 2003. Managing brand in the new stakeholder environment. Journal of Business Ethics 44: 235-46.

Margolis, J., and J. Walsh. 2001. People and profits? The search for a link between a company's social and financial performance. New Jersey: Lawrence Erlbaum Associates Publishers.

Marquez, A., and C. Fombrun. 2005. Measuring Corporate Social Responsibility. Corporate Reputation Review 7, no. 4: 304-08.

McGuire, J. 1963. Business and society. New York: McGraw-Hill.

McGuire, J., A. Sundgren, and T. Schneeweis. 1988. Corporate Social Responsibility and firm financial performance. Academy of Management Journal 31, no. 4: 854-72.

McWilliams, A. 2001. Corporate Social Responsibility: A theory of the firm perspective. Academy of Management Review 26, no. 1: 117-28.

Metcalfe, C. 1998. The stakeholder corporation. Business Ethics: A European Review 7, no. 1: $30-6$.

Milne, M., and R. Adler. 1999. Exploring the reliability of social and environmental disclosures content analysis. Accounting, Auditing and Accountability Journal 12, no. 2: 237-49.

Mitchell, R., B. Agle, and D. Wood. 1997. Toward a theory of stakeholder identification and salience: Defining the principle of who and what really counts. Academy of Management Review 22, no. 4: 853-96.

Mitnick, B. 2000. Commitment, revelation, and the testaments of belief: The metrics of measurement of corporate social performance. Business \& Society 39, no. 4: 419-56.

Moore, G. 2001. Corporate social and financial performance: An investigation in the UK supermarket industry. Journal of Business Ethics 34, no. 3-4: 299-315.

Nafez, A., and N. Kamal. 2000. Empirical evidence on corporate social disclosure practices in Jordan. International Journal of Commerce and Management 10, no. 3/4: 18-35.

Neville, B., and B. Menguc. 2006. Stakeholder multiplicity: Toward an understanding of the interactions between stakeholders. Journal of Business Ethics 66: 377-91.

O'Dwyer, B. 2003. Conceptions of corporate social responsibility: The nature of managerial capture. Accounting, Auditing and Accountability Journal 16, no. 4: 523-7.

Orts, E., and A. Strudler. 2002. The ethical and environmental limits of stakeholder theory. Business Ethics Quarterly 12, no. 2: 215-33.

Owen, D., T. Swift, C. Humphrey, and M. Bowerman. 2000. The new social audits: Accountability, managerial capture or the agenda of social champions. European Accounting Review 25, no. 3: 81-99.

Philips, R. 2004. Ethics and managers obligation under stakeholder theory. Ivey Business Journal March/April: 1-4. 
Podnar, K., and Z. Jančič. 2006. Towards a categorization of stakeholder groups: An empirical verification of a three-level model. Journal of Marketing Communications 12, no. 4: 297-308.

Rasche, A., and D. Esser. 2006. From stakeholder management to stakeholder accountability. Journal of Business Ethics 65: 251-67.

Reynolds, S., F. Schultz, and D. Hekman. 2006. Stakeholder theory and managerial decisionmaking: Constraints and implications of balancing stakeholder interests. Journal of Business Ethics 64: 285-301.

Robertson, D., and N. Nicholson. 1996. Expressions of Corporate Social Responsibility in UK firms. Journal of Business Ethics 15: 1095-106.

Ruf, B., K. Muralidhar, R. Brown, J. Janney, and K. Paul. 2001. An empirical investigation of the relationship between change in corporate social performance and financial performance: A stakeholder theory perspective. Journal of Business Ethics 32: 143-56.

Sachs, S., M. Maurer, E. Rühli, and R. Hoffmann. 2006. Corporate Social Responsibility for a "stakeholder view" perspective: CSR implementation by a Swiss mobile telecommunication provider. Corporate Governance 6, no. 4: 506-15.

Sen, S., C. Bhattacharya, and D. Korschun. 2006. The role of Corporate Social Responsibility in strengthening multiple stakeholder relationships: A field experiment. Journal of the Academy of Marketing Science 34, no. 2: 158-66.

Simpson, G., and T. Kohers. 2002. The link between corporate social and financial performance: Evidence from the banking industry. Journal of Business Ethics 35: 97-109.

Spence, L., A. Coles, and L. Harris. 2001. The forgotten stakeholder? Ethics and social responsibility in relation to competitors. Business and Society Review 106, no. 4: 331-52.

Spence, L., R. Jeurissen, and R. Rutherfoord. 2000. Small business and the environment in the UK and the Netherlands: Toward stakeholder cooperation. Business Ethics Quarterly 10, no. 4: 945-65.

Stempel, G. 1981. Research methods in mass communication, eds. G. Stempel and B. Westley. New Jersey: Prentice Hall.

Sturdivant, F., and J. Ginter. 1977. Corporate social responsiveness, management attitudes and economic performance. California Management Review XIX, no. 3: 30-9.

Thorne, D., O. Ferrell, and C. Ferrell. 2003. Business and society: A strategic approach to corporate citizenship. Boston: Houghton Mifflin Company.

Vos, J. 2003. Corporate Social Responsibility and the identification of stakeholders. Corporate Social Responsibility and Environmental Management 10, no. 3: 141-52.

Waddock, S., and S. Graves. 1997. Finding the link between stakeholder relations and quality of management. Journal of Investing 6, no. 4: 20-5.

Wulfson, M. 2001. The ethics of corporate responsibility and philanthropic ventures. Journal of Business Ethics 29: 135-45. 
Copyright of Journal of Marketing Communications is the property of Routledge and its content may not be copied or emailed to multiple sites or posted to a listserv without the copyright holder's express written permission. However, users may print, download, or email articles for individual use. 
Copyright of Journal of Marketing Communications is the property of Routledge and its content may not be copied or emailed to multiple sites or posted to a listserv without the copyright holder's express written permission. However, users may print, download, or email articles for individual use. 